\title{
Circuit
}

Musiques contemporaines

\section{Electroacoustic Music and the Digital Future}

\section{Barry Truax}

Volume 13, numéro 1, 2002

L'électroacoustique : à la croisée des chemins?

URI : https://id.erudit.org/iderudit/902261ar

DOI : https://doi.org/10.7202/902261ar

Aller au sommaire du numéro

Éditeur(s)

Les Presses de l'Université de Montréal

ISSN

1183-1693 (imprimé)

1488-9692 (numérique)

Découvrir la revue

Citer cet article

Truax, B. (2002). Electroacoustic Music and the Digital Future. Circuit, 13(1), 21-26. https://doi.org/10.7202/902261ar

\section{Résumé de l'article}

Cet article présente les points de vue de l'auteur sur la situation sociale et économique actuelle de la musique électroacoustique et de la technologie numérique en général. Il fait ressortir la prédominance des intérêts commerciaux tant dans le conditionnement de l'auditeur et de l'artiste que dans la définition de la culture. Les questions soulevées par la technologie numérique, comme la standardisation, la " désexpertisation » (de-skilling) et les mises à niveau (upgrades) sont examinées en rapport avec la pratique artistique. L'auteur conclut que les formes d'art marginales comme l'électroacoustique ont bénéficié des possibilités de « naviguer » (windsurfer) qu'offre le poste de travail audionumérique (DAW) pour la production et l'Internet pour la distribution. Mais aucune avenue analogue n'existe pour la création du consommateur.
Ce document est protégé par la loi sur le droit d'auteur. L'utilisation des services d'Érudit (y compris la reproduction) est assujettie à sa politique d'utilisation que vous pouvez consulter en ligne.

https://apropos.erudit.org/fr/usagers/politique-dutilisation/ 


\title{
Electroacoustic Music and the Digital Future
}

\author{
Barry Truax
}

The relation of music and technology is increasingly paradoxical. Within musical thought, digital technology allows the composer to conceive musical ideas from strikingly new perspectives. At the same time technology allows music to be increasingly imbedded within the media environment as a commodity with more exchange value than use value. Music frequently functions as a surrogate environment that interposes itself between us and the external world, imposing the relationship we have to an environment (e.g., making us feel "happy") instead of expressing our relationship to that environment. Music as an expression of the human spirit is locked in a struggle with music as the product of corporate control. In such a situation, it is far from clear what the role of creative musical education should be today: training for the marketplace or sandbagging the crumbling foundations of the museum of past accomplishments against the wavewash of the corporate agenda.

In the 20th century, the electrical, then electronic and now digital technology which created the visually dominant mass media have also produced an equally powerful electroacoustic technology which I will contend has profoundly changed not only the soundscape, but also the individual practice of listening and the social behaviour it leads to. Here then is the paradox: we live in a visually dominant culture that is saturated with technologically based sound, much of which we take for granted or ignore. Some of this sound is the byproduct of our various technologies, the noises, whirs and hums that, if we are lucky, merely form the background to daily life, and if we are not, add to the stress on our bodies and minds. However, much of our daily aural experience includes sound that is reproduced through loudspeakers. It can come from hidden sources or obvious ones, hugely powerful devices or personal attachments that speak only to our own ears. The sound may be live from across the city, the nation or the world, or more likely, a replay from across the years. It can be the voice of a person we know so well that visual recognition is unnecessary, or the anonymous yet seductive voice of those acting as 
mouthpieces for commerce or the state. It can be sound that we have chosen to listen to, even if we subsequently relegate it to the background of our attention, or sound that has been chosen for us, with or without our permission. It can be broadcast, narrow-cast, copied, purchased, consumed, digitized, packaged, archived and catalogued. Despite its amorphous and volatile character, I will characterize this complex web of communication practices as the electroacoustic community.

Electroacoustic technology is striking in its ability to treat sound as a commodity as audio products package the listening experience in economic terms. The control over the production and distribution of such commodities defines what is accessible to the consumer. Despite the potential for infinite variety, commodity culture actually restricts variety to a number of semi-identical products that compete for market share. It is not surprising to find fewer than half a dozen formats as one sweeps the radio dial in most places, just as most record stores limit their stock to a few styles of music.

In North America it is not only popular culture that is defined by "what sells". Public culture - that is, culture recognized for its social merit rather than its economic viability - is increasingly being defined by the same criterion. As government support of public culture is eroded, the mass media increasingly marginalize those aspects of culture that are not driven by commercial interests such as publishers, promoters and corporate sponsorship. In Canada, novelists, visual artists, filmmakers and performers who have substantial financial backing are promoted by the media and, hence, recognized by the public as the cornerstones of Canadian culture. On the other hand, composers, poets, playwrights and many other kinds of artists not as easily capitalized, go unrecognized. The net result is that the public's awareness of the full range of cultural voices becomes narrowed. In North America we look enviously at the richness of the cultural scene in Europe which has traditionally found a better balance between public and private interests, but we now hear rumours of cutbacks and funding problems even in those countries.

The reversal of this particular trend seems to be the most difficult of all to deal with, and considerable ingenuity needs to be involved for the individual to create an alternative path. However, countless artists and sound designers are building up their own resources, often in their own homes, and finding ways of producing and distributing their work that is largely ignored by the mass media. For instance, I have created my own record label, Cambridge Street Records Inamed for where I live) complete with website and distribution arrangements with a variety of organizations worldwide devoted to making alternative forms of music, such as electroacoustic music, available. Therefore, for me and many other sound artists, electroacoustic technology has become both a liberating creative tool and an effective distribution medium whereby our most imaginative experiences with sound can be shared world-wide. However useful this personal access to technology may be, a suspicion lingers about the inevitable standardization of the cre- 
ative process which the use of commercial hardware and software encourages in the form of the contemporary digital audio workstation (DAW). In an increasingly commoditized culture where the very notion of culture is defined by what receives the greatest promotion and generates the most revenue, where will young artists find a creative path?

\section{The digital future}

As the electronic revolution gives way to the digitization of all forms of information and communication, we face both the prospect of the elimination of aurality las visual and print information dominate computer-based communication), and the simultaneous promise of multi-media where both modalities will presumably exist side by side within the data format of one's choice. Both the disturbing and exciting elements of these scenarios attract our attention, and I suggest that some insight into the dilemmas each poses can be gained by a careful examination of the contemporary practice of media and electroacoustic music as it ranges from the mass product to the marginalized practices of the creative community.

The Canadian historian and early communication theorist, Harold Innis', proposed a model that deals with the relationship of the centre to the margins, initially as an economic model where raw resources flowed from the geographical margins to the industrialized centres of power where they were turned into marketable goods that flowed outwards again. In the modern digitally mediated world, there is clearly no geographic centre; instead, the mainstream is defined economically as the mass market, with alternative cultural practices marginalized as niche interests with little economic potential. Cultural activities are caught in a series of marginal positions: electroacoustic music lies at the margins of contemporary music, which lies at the margins of classical music, which lies at the margins of the fine arts, which lies at the margins of the commercial entertainment industry, and it is that industry which increasingly in North America seems to be calling the shots.

The key element in commodity culture is not the creation of products, but rather the production of the consumer, mainly through advertising and media exposure. The $20^{\text {th }}$ century, the first audio century, is remarkable for, among many other things, the creation of the electroacoustic listener as a consumer. A hundred years later it is difficult for us to imagine the beginning of that era when a sound was first heard for a second time, when voices and music started emanating from inanimate objects called "speakers" (with such fidelity that a dog could recognize its master's voice), when recorded music could be bought and sold, when sounds could be in a space, but not be of that space. Besides making these magic-like practices acceptable, a consumer had to be created who implicitly believed that technical

1. INNIS, H. (1972) Empire and Communication, University of Toronto Press. 
progress would result in an increased value of sound-as-commodity. An analytical style of listening had to be developed whereby the quality of sound could be separated from the sound itself (keep in mind that all acoustic sound has the same degree of quality) with progressively finer distinctions being made until some ears became "golden" like the taste buds of a connoisseur of fine wines.

The same process of consumer education continues today with digital technology, with many similar beliefs and degrees of technical knowledge being inculcated by the industry. For instance, it's a commonly held belief that digital sound is superior, that it gives perfectly reproduced fidelity, that background noise can be eliminated (particularly with cell phones), and most importantly, that it is worth paying for. My point is not to debate these beliefs from a technical perspective, though even the most casual observer realizes that background noise is present in all forms of audio communication, that distorted sound is commonplace, and that the beeps and buzzes that populate the daily soundscape now are inferior sounds, despite that fact they are produced digitally, often in a poor imitation of acoustic music. Instead, these developments point to the fact that both creators and listeners are the producers and consumers of audio products. There is a similar belief that "everything's on the Internet". Although it is remarkable how much information is indeed accessible, it is also clear that there are no methods (the equivalent of peer review) to validate such information, nor to ensure that the information gatekeepers are not biased. Activists proclaim that "information wants to be free" - it would probably be more accurate to say that we want it to be free - but as soon as a challenge is mounted, it becomes clear that vested corporate interests are prepared to go to great lengths to protect their property and investments (usually by an appeal to the individual artist's intellectual property rights!).

Although the technological implications of the digital future continue to unfold with increasing complexity, I think that the basic issues, struggles and options I have outlined remain the same. In many ways, the listener is still the central entity around which swirl the winds of technological change. Listening is not merely a way of receiving and decoding information, although that function is still very important; listening also mediates all of our relationships - with others, the environment, society in general, and even ourselves. It creates links and patterns, and as we have discussed, the new patterns of the electroacoustic community, based as they are in paradox and contradiction, are complex and move in opposite directions. In one direction, listening is devalued, marginalized, and exploited as a consumer activity; in the other, it is the means by which we can more intensively engage our own society, and cultural history as a whole, as well as the unbounded world of the imagination.

So where does this leave electroacoustic music as we now understand it? As a cultural practice, both its "serious" and "popular" forms (with only arbitrary divisions between those two extremes) are marginalized, even though it is almost exactly the same technology being used within the electroacoustic music community as within 
mainstream commercial production, perhaps less lavish than the commercial version, but still recognizably similar. Will the ready availability of the means of production (the DAW) and distribution (self-produced CD's and the Internet) change the marginalized situation of the electroacoustic composer? As useful and impressive as these desktop technologies are, I believe the ultimate answer is unfortunately no. What is missing is one of the most important elements: the creation of the consumer. Advertising and promotion are traditionally the required elements, not browsers casually surfing the Internet. The advertising budgets of corporations are typically 10 times the costs of production, showing how important they regard the creation of the consumer. Hence it is not surprising that when the traditional "high culture" organizations have to compete in the marketplace, they are at an extreme disadvantage. Traditionally, they spend most of their budgets on producing a high quality product whereas now the product must be produced cheaply and marketed heavily. For instance, so-called "designer CD's" of popular classics are the only ones reaching significant levels of sales today. The traditional means of creating the arts consumer has been education, not advertising, but today, dwindling government support for schools has meant reduced arts education and increased opportunities for private enterprise to fund computer use in the schools. And media exposure, as the "street" version of education, favours only capitalized forms of cultural endeavours.

Of equal concern is the trend towards de-skilling that accompanies the proliferation of digital technology. Although the most serious implications involve the workplace, similar concerns accompany the wide-spread use of plug-in software and preset effects. Critics of such automation point to the "dumbing down" of the production process, presumably in the desire for greater accessibility and hence marketability. Even when such processors allow the user to control individual parameters, the question remains as to how the user develops knowledge to understand and use such parameters skillfully. Education of the consumer is generally restricted to education as consumer, not as user. On the other hand, this leaves the door open for public education institutions to fill these gaps, acting as a buffer between the academic research community and the commercial world.

One final factor is that, with the dependency of the artist on commercially avaitable tools, the design, maintenance, and upgrade of these tools are placed in the hands of those who are generally without artistic experience or commitment. In any case, the tools are not being designed for artists whose needs are notoriously idiosyncratic. The result is a proliferation of general purpose tools, supplemented by a smorgasbord of specialized software of varying compatibility. Of course, artists have traditionally found and adapted their techniques to the available materials, but at least those tools and materials remained stable. The economic imperative for constant change (the belief in the "upgrade" as continual progress) is clearly antithetical to the stability traditionally associated with artistic practice. It took a century or more to work out the musical implications of the change from the harpsichord to the piano; what if the instrument changed every few years! 
Digital artists (much like the public in general) have to be clever in their negotiation of such a volatile landscape. Many will admit, perhaps sheepishly, that they aren't using "the latest and greatest". My own case is somewhat extreme in that regard, as I am using a hardware system (DEC computer and DMX-1000 signal processor) that was introduced over 20 years ago, and only my own software (the PODX system) that I have developed and used for over 30 years! Fortunately I have been able to benefit from modern technology as well, with a digital 8-track recorder (Tascam DA-88) and computer-controlled diffusion system (AudioBox), but I prefer to work compositionally with what I know best - a real-time software/hardware system that is controlled from a computer keyboard with no graphics. An unthinkable configuration for my students, but it works for me.

Given all of these problems, will the artistic impulse survive? Of course it will, because it is a human necessity. Will it flourish and be an active part of our culture - not likely. Both traditional cultural institutions and marginalized newer practices will be squeezed even further by the overblown mainstream domination of culture, as supported by the commercial media, and even increasingly by publicly funded broadcasters. And the next generation of young artists? Some of them will undoubtedly discover creative means to survive and possibly even exploit the paradoxical situation in which they find themselves. Their post-modern sensibility seems to allow them to switch between all manner of cultural styles without being disturbed by their mutual incompatibility. They may even re-invent the old adage about art for art's sake. It used to have a slightly pejorative ring of elitism to it, but in the future it may come to represent something so important that it's worth doing for its own sake, independent of public support or recognition.

Barry Truax's Website: www.sfu.ca/ truax

\section{References}

EMMERSON, S., ed., (2000), Music, electronic media and culture, London, Ashgate, $272 \mathrm{p}$.

INNIS, H.A. (1972), Empire and communications, revised by M. Q. Innis, Toronto, University of Toronto Press.

THÉBERGE, P. (1997), Any sound you can imagine: Making Music/Consuming Technology, Hanover, NH, Wesleyan University Press.

TRUAX, B. (2001) [1984], Acoustic communication, 2nd ed., Ablex Publishing. 